Mackenzie-then chief of surgery). What distinguished Dr Lewis from the outset was his confidence. He never had second doubts; he never wavered when faced with a life threatening emergency. Although very cautious in terms of patient selection, he was audacious as a technical surgeon. On my first official rotation with him as a second-year resident, I knew that I would always be a thoracic surgeon. We had what would be called today multidisciplinary conferences, which usually revolved around whether a computed tomographic scan should be performed or whether a tissue diagnosis by computed tomographic guidance or bronchoscopy was appropriate. $\mathrm{He}$ was a firm believer in routine mediastinoscopy and taught me the concept of "med on Monday and thoracotomy on Wednesday (or the following Monday!). He was, with his partner Dr James Mackenzie, one of the first proponents of routine thoracoscopy, then using a standard mediastinoscope for pleural disease. This early exposure to "rigid thoracoscopy", obviously later led to my interest in utilizing newer technology in helping to develop video-assisted thoracoscopic surgery once in practice. He firmly believed that any surgery for mesothelioma should be done only for palliation, because there was no way to cure these patients surgically. $\mathrm{He}$ arrived at this conclusion after personally doing dozens of autopsies on these patients and demonstrating microscopic invasion into the endothoracic fascia and chest wall. Although the concept of combined modality therapy had not yet gained acceptance, he at least used routine surgical staging of mesothelioma and non-small cell lung cancer to refer patients for definitive nonoperative therapy in cases of positive findings.

My first transforming experience with him was when I was secondyear resident, assisting on a transhiatal esophagectomy. The chief resident cut the left hepatic vein flush with the in- ferior vena cava, and the patient began to exsanguinate. I immediately put my hand on the cava, and asked for a sternal saw. He looked at me, somewhat bewildered, and said, "Can you do this?" to which I promptly replied, "Yes." After he said to go ahead, and I controlled the avulsed cava intrapericardially and repaired the left hepatic vein-caval junction below (with 3-0 silk!), I was a constant presence on his major cases for the next 4 years of my training. I got to know his sense of humor, practical approach to problem solving, and personal contact with each of his patients firsthand. From placing the arterial line and double-lumen tube preoperatively to intensive care unit and ventilator management postoperatively, Dr Lewis was a constant presence in his patients' postoperative care. I vividly remember him teaching me how to do chest physiotherapy with percussion and incentive spirometry, so that I could teach the nurses and therapists when the need arose.

I have a very personal debt to $\mathrm{Dr}$ Lewis, who introduced me to my next mentor, Dr F. Henry (Bunky) Ellis, Jr. I am convinced that if not for his belief that I would make a successful academic thoracic surgeon, I would never have gotten into the prestigious New England Deaconess program in 1988.

After completing my training at Harvard, I was fortunate to get to know Ralph, as he now insisted on being called, on a much more personal basis. We met each other frequently and debated with each other constantly on the different aspects of thoracoscopy developed as we both tried to push the field in our own directions. Ralph believed that smaller operations would allow "other therapies" to complement the operation and achieve good long-term results, while I was committed to a conservative, standard oncologic approach with smaller incisions. Even this competition was fruitful, as I later found out that he single-handedly helped all the Young Turks of the thoracoscopy era (Landraneau, Hazelrigg, Naunheim, Mack, Krasna, and so on) to get published in the Annals of Thoracic Surgery (under the careful eye of Dr Tom Ferguson).

Ralph's contributions to the field of thoracic surgery include articles and presentations at national meetings. Most importantly, he was the dominant force in thoracic surgery for New Jersey for more than 3 decades and trained numerous future cardiac and thoracic surgeons in the field of general thoracic surgery at a time when there were few American surgeons who had dedicated themselves to our subspecialty. His humor, warmth, and frank, outspoken nature will be missed by us all.

Mark J. Krasna, MD Division of Thoracic Surgery St. Joseph's Medical Center Towson, $M d$

doi:10.1016/j.jtcvs.2010.11.040

\section{GENTLE GIANT: WILFORD NEPTUNE, MD}

To the Editor:

Wilford B. Neptune passed away on April 3, 2010.

My favorite vignette of Dr Neptune is definitely my last case operating with him and his senior partner, Dr Richard Overholt, at the New England Deaconess Hospital in Boston in the spring of 1990. Imagine the scene. The patient is in the prone position,

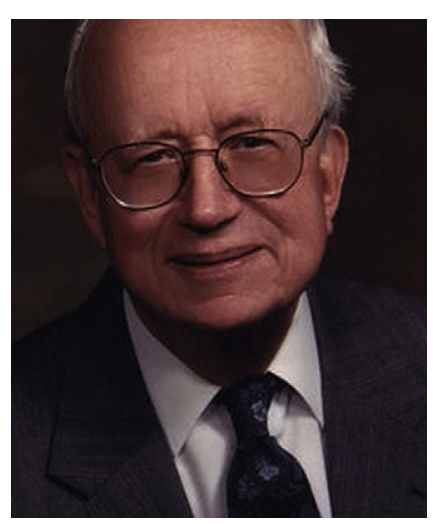




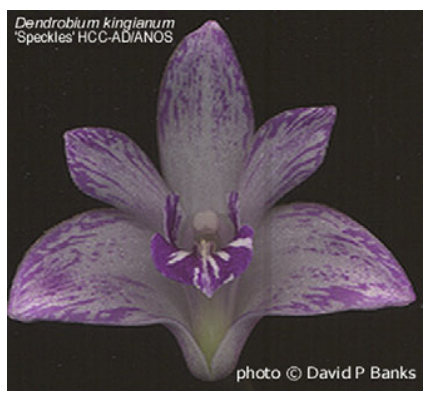

on an Overholt table, about to undergo a posterior thoracotomy and superior segmentectomy. Dr Overholt, 88 years old (approximately) at the time, comes into the room after scrubbing (only up to his wrists because of being cold; the head nurse would allow him to wear long-sleeved undershirts!). After him comes Dr Wilford Neptune, then about 68 years old, his "junior partner," to first assist. My role is to act as second assistant. In fact, it is to simply bear witness to this final historic operation with 2 giants in the field of thoracic surgery. Despite their advanced ages (combined, their age is almost 160 years!), their complete disregard for bleeding and anatomic challenges allows them to perform a standard posterior thoracotomy, cutting 3 ribs and allowing the blood to pool on the floor, in less than $1 \frac{1}{2}$ hours.

As I learned through the years from "Nep," as he was fondly referred to by his residents, he was a master surgeon who didn't crave the limelight.
"I remember when Charlie Bailey and I did the first..." was the beginning of many wonderful historical tales that he shared during the years I had the honor to train with him. At a time when most of his partners were doing standard open thoracotomies for esophagectomies, it was the elder Dr Neptune who taught us how to do transhiatal esophagectomies. I later learned that, much like my other mentor, Dr F. Henry (Bunky) Ellis, Jr, Nep had an illustrious career as a heart surgeon in addition to being a master thoracic surgeon. He was doing valvotomies and commisurotomies when most people were standing on the sidelines with this novel approach to mitral valve disease. He performed some of the earliest angiography in Boston, performing left heart catheterizations through a rigid bronchoscope with direct cannulation of the left atrium, and he did his share of the famed Vineberg operations with implantation of the internal thoracic artery onto the pericardium. In addition, he is credited by his family and residents with defining hemodilution as a method of safely using cardiopulmonary bypass.

Through it all, he was one of the kindest, gentlest and soft spoken of the giants that I had the privilege to work with. I well remember him visiting me when I was a junior fellow presenting a poster at the American College of Chest Physicians. He walked over and said hello to my wife, Diane, and our two little girls, beaming with pride as though he were their grandfather.

His caring for his residents and fellows probably was an offshoot of his caring for his orchids, which he did avidly throughout his life, even receiving numerous awards, among them one from the British Royal Horticultural Society. Between 2001 and 2008, Dr Neptune donated his entire orchid collection to Smith College, in Northampton, Massachusetts, where it will be used in teaching botany, landscape architecture, and art. It will also be part of the standing collection for public viewing, which currently receives 60,000 visits per year. Dr Neptune was an honorary member of the Massachusetts Orchid Society. $\mathrm{He}$ received a lifetime achievement award in 2000 from the Massachusetts Orchid Society and a similar award the following year from the Cape and Islands Orchid Society.

Dr Neptune will be sorely missed by the generations of Boston surgeons who had the privilege to work with him. We will long remember his humility, warmth and honesty.

Mark J. Krasna, MD Division of Thoracic Surgery St. Joseph's Medical Center Towson, $M d$ doi:10.1016/j.jtcvs.2010.11.041

\section{Notice of Correction}

Re: Wang J, Liu H, Xiang B, Li G, Gruwel M, Jackson M, Tomanek B, Salerno TA, Deslauriers R, Tian G. Keeping the heart empty and beating improves preservation of hypertrophied heart for valve surgery. J Thorac Cardiovasc Surg. 2006;132:1314-20.

In the above-noted article, the aortic banding period of pigs was inadvertently stated as 12 weeks. In fact, the aortic banding period was 8 weeks for induction of left ventricular hypertrophy in this study. The incorrect aortic banding period was stated in: (1) the first line in the section "Methods" in the abstract (p 1314); (2) the last line of the section "Pig Model of PressureOverloaded Left Ventricular Hypertrophy" in "Materials and Methods" (p 1315); (3) the first line in the section "Isolated Pig Heart Preparation" in "Materials and Methods" (p 1315); and (4) the second-to-last line in the section "Myocardial Hypertrophy" in "Results" ( $p$ 1317). The animals developed significant myocardial hypertrophy following 8 weeks of aortic banding. As a result, the above error does not affect the results and conclusion of the article. 